\title{
IMPROVEMENT IN THROMBOCYTOPENIA AFTER CARVEDILOL USE IN HEPATITIS C CIRRHOTIC PATIENTS.
}

\begin{abstract}
Muhammad Jahangir Mujahid', Sobia Khalid², Shehla Mujahid ${ }^{3}$, Muhammad Riaz ${ }^{4}$, Khurram Malik $^{5}$, Arif Amir Nawaz ${ }^{6}$

ABSTRACT: Carvedilol is a $\beta$-blocker (non-selective). It causes vasoconstriction in the splanchnic vessels and causes reduction of portal inflow. Hence this change causes less destruction of platelets in the patients having splenomegaly with portal hypertension and cirrhosis. Objectives: The objective of the study is to find out the effect of carvedilol on thrombocytopenia in cirrhotic patients of hepatitis C. Study Design: Descriptive study. Settings: Department of Gastroenterology, Fatima Memorial Hospital, Lahore. Period: Six months from $17^{\text {th }}$ October 2015 to $16^{\text {th }}$ April 2016. Material \& Method: Data was collected using designed proformas. All patients with hepatitis $\mathrm{C}$ having cirrhosis of liver, splenomegaly and a platelet count of less than $100,000 / \mathrm{mm} 3$ were included after taking informed consent. Dose of carvedilol was managed so that $25 \%$ reduction in heart rate was achieved. Platelet count was repeated after two weeks. Blood pressure, pulse and platelet count before and after $25 \%$ reduction in heart rate with carvedilol was compared. Changes in platelet count, blood pressure, pulse and dose of carvedilol were also calculated. $<0.05$ p value was taken as significant. Results: A total of $66 \%$ patients responded to carvedilol therapy and showedmean rise in platelet count of 16 \pm 10.3. (P-Value <0.05). Changes in platelet count with change in blood pressure, pulse and with dose of carvedilol were found to be significant. $(\mathrm{P}<0.05)$. Conclusion: Carvedilol causes improvement in thrombocytopenia in cirrhotic patients.
\end{abstract}

Key words: $\quad$ Cirrhotic Patients, Carvedilol, Hepatitis C, Thrombocytopenia.

Article Citation: Mujahid MJ, Khalid S, Mujahid S, Riaz M, Malik K, Nawaz AA. Improvement in Thrombocytopenia after Carvedilol use in Hepatitis C cirrhotic patients. Professional Med J 2019; 26(12):2070-2074. DOI: 10.29309/TPMJ/2019.26.12.3054

\section{INTRODUCTION}

Hepatitis $\mathrm{C}$ virus (HCV) has the annual frequency of 170 million people worldwide. ${ }^{1}$ Almost $80 \%$ of the infected patients progress to chronic hepatitis and as much as $30 \%$ advance to cirrhosis. ${ }^{1,2}$ It is considered that $25 \%$ of the HCV infected patients develop hepatocellular carcinoma (HCC). ${ }^{2,3}$ In 2002, among 1.4 million deaths associated with chronic liver disease (CLD), more than 280,000 deaths were due to HCV-related liver disease. ${ }^{4,5}$ In Pakistan, hepatitis $\mathrm{C}$ virus infection is the most common cause of cirrhosis. ${ }^{6}$ In Karachi, according to a study, out of 2965 general patients $379(12.8 \%)$ were anti-HCV positive. ${ }^{7}$ The most serious and worrisome complication of cirrhosis is portal hypertension. As the normal pressure in the portal vein is $5-10 \mathrm{mmHg}$. In case of portal hypertension the pressure rises to $12 \mathrm{mmHg}$ or more due to dilatation of venous channels. Hence it leads to the formation of collaterals with the systemic venous system; the most important site is at the gastro esophageal junction. Here it leads to the development of esophageal and gastric varices. These varices are fragile and can get ruptured leading to life threatening upper gastrointestinal bleeding. ${ }^{8}$ It is the hypersplenism due to portal hypertension that leads to thrombocytopenia. This adds to the grave morbidity and mortality of gastrointestinal bleeding. ${ }^{9}$

If it is possible to reduce the portal pressure, the variceal bleedingcan minimize. It in turn reduces the destruction of platelets in the enlarged spleen. Hence if this is required, a medical therapy with beta blockers like propranolol or carvedilol can be helpful. ${ }^{10}$ With propranolol there was an increase in platelet count in $62.7 \%$ of patients of cirrhosis with portal hypertension. ${ }^{11}$ Carvedilol is another 
beta blocker, a non-selective one, which causes vasoconstriction of the splanchnic arteries. It has an effect of unopposed alpha vasoconstriction resulting from blockade of beta receptors. It also causes reduction in portal inflow as it lowers the cardiac output, heart rate and contractility. Hence it can be a better choice than propranolol. ${ }^{9}$ In Pakistan hepatitis $\mathrm{C}$ related cirrhosis is notuncommon. The most frequent presentation of the patients is upper gastrointestinal bleeding. This bleeding is secondary to variceal bleeding and thrombocytopenia. Hence the purpose of this study is to observe the effect of carvedilol on low platelet count in patient's withportal hypertension\& hepatitis C related cirrhosis. As it is obvious from the results of a study that carvedilol reduces the portal hypertension in a better way than other beta blockers ${ }^{12}$ and so it is proposed that in turn it may be effective to correct thrombocytopenia. Therefore it is likely to decrease the morbidity and mortality related to upper gastrointestinal bleeding and the need for repeated hospitalizations as well as treatment cost will also be cut down.

\section{METHODS}

A descriptive study was done in the Department of Gastroenterology, Fatima Memorial Hospital, Lahore. In a period of six months from $17^{\text {th }}$ October 2015 to $16^{\text {th }}$ April 2016 a total of one hundred and fifty cases of Hepatitis $C$ related cirrhosis associated splenomegaly and thrombocytopenia were included in the study through a convenient sampling. ELISA was used to diagnose all patients with hepatitis C. However cirrhosis \& splenomegaly were diagnosed on ultrasound. Patients with platelet count of less than 100,00/ mm3 were included in the study. However, those with pregnancy, heart rate of less than $60 / \mathrm{min}$ were excluded from the study. An informed and signed consent was taken. After a detailed history, a complete physical examination was carried out with particular emphasis on the patient's blood pressure and resting heart rate. All patients were guided for hematological investigations. Blood samples were drawn at first presentation and anti-coagulated blood was used to determine baseline platelet count. Platelet count was checked using the Caulter counter. The patients were given carvedilol and its dose was adjusted so as to achieve a $25 \%$ reduction in baseline heart rate. Their blood pressure was again recorded after target heart rate achieved. After 2 weeks of achieving the required heart rate, a platelet count was repeated. It was decided to continue carvedilol in all patients even after completion of the study because the drug has been known to improve portal hypertension. All the above information was collected on a proformas.

\section{RESULTS}

A total of 150 patients were included in the study. The mean age was $51.9 \pm 8.88$ years. Majority of the patients were 41 to 50 years of age. The males were $62 \%$ and females were $38 \%$. Gradual increase in abdominal girth was seen in $49 \%$ patients and pedal edema was also seen in $49 \%$ patients. These two clinical features were the most common presenting complaints seen followed by pain epigastrium and vomiting which had 40\% frequency. Fever and generalized abdominal pain was seen in $27 \%$ patients. However $14 \%$ patients presented with symptoms other than those mentioned in Table-l. The mean systolic blood pressure before and after treatment with carvedilol was135 $( \pm 11.5, p<0.05)$ and 117 $( \pm 10.6, p<0.05) .17( \pm 6.6, p<0.05)$ was the mean difference in systolic blood pressure. As far as the mean diastolic blood pressure before and after treatment with carvedilol is concerned it was found to be 84 ( $\pm 7.2, p<0.05)$ and 75 ( \pm 7.5 , $\mathrm{p}<0.05)$ respectively. The mean difference was 8 $( \pm 5.2, p<0.05) 101 \pm 8.3$ and $90 \pm 8.4(p<0.05)$ was the mean arterial blood pressure before and after treatment with carvedilol was respectively. The mean difference was $11.5( \pm 5, p<0.05)$. Similarly96 $( \pm 9.3, p<0.05)$ and $76( \pm 7.6$, $p<0.05)$ respectively, was the mean pulse before and after treatment with carvedilol. (Table-II) The mean difference however was $20( \pm 6.6 p<0.05)$.

Sixty six percent (66\%) of patients responded to carvedilol therapy (Table-II). After treatment with carvedilol the mean platelet count before and after was $62( \pm 21, p<0.05)$ and $78( \pm 25 p<0.05)$ respectively. Mean difference in was $16( \pm 10.3$ $p<0.05$ ). (Table-V). A $12.5 \mathrm{mg}$ of carvedilol was requiredin 65 patients to achieve target heart rate. 
Mean dose required was 19.37 \pm 5.76 (Table-III). Correlation coefficients as shown in Table-IV for change in platelet count with change in systolic blood pressure, pulse and dose required was significant $(p<0.05)$ but those with diastolic blood pressure and mean arterial blood pressure was not $(p>0.05)$

\begin{tabular}{|c|c|c|c|}
\hline \multicolumn{3}{|c|}{ Presenting complaints } & Percentage \\
\hline \multicolumn{3}{|c|}{$\begin{array}{l}\text { Increasing Abdominal Distension and } \\
\text { Pedal edema }\end{array}$} & 49 \\
\hline \multicolumn{3}{|c|}{ Pain epigastrium and vomiting } & 40 \\
\hline \multicolumn{3}{|c|}{ Generalized Abdominal pain and fever } & 27 \\
\hline \multicolumn{3}{|c|}{ Bleeding tendencies } & 18 \\
\hline \multicolumn{3}{|c|}{ Deepening of jaundice and drowsiness } & 16 \\
\hline \multicolumn{3}{|l|}{ Total } & 150 \\
\hline \multicolumn{4}{|c|}{ Table-I. Frequency of presenting complaints } \\
\hline Variable & $\begin{array}{l}\text { Pre } \\
\text { treatment }\end{array}$ & $\begin{array}{l}\text { Post } \\
\text { treatment }\end{array}$ & $\begin{array}{l}\text { Signi- } \\
\text { ficance }\end{array}$ \\
\hline $\begin{array}{l}\text { Systolic blood } \\
\text { pressure }\end{array}$ & $135 \pm 11.5$ & $117 \pm 10.6$ & $<0.05$ \\
\hline $\begin{array}{l}\text { Diastolic blood } \\
\text { pressure }\end{array}$ & $84 \pm 7.2$ & $75 \pm 7.5$ & $<0.05$ \\
\hline $\begin{array}{l}\text { Mean arterial } \\
\text { blood pressure }\end{array}$ & $101 \pm 8.3$ & $90 \pm 8.4$ & $<0.05$ \\
\hline Pulse & $96 \pm 9.3$ & $76 \pm 7.6$ & $<0.05$ \\
\hline Platelet count & $62 \pm 21$ & $78 \pm 25$ & $<0.05$ \\
\hline
\end{tabular}

Blood Pressure in $\mathrm{mmHg}$; Pulse: in beats per min Platelets count: 1000/microlitre

\begin{tabular}{|c|c|}
\hline Dose of Carvedilol $(\mathbf{m g})$ & Frequency \\
\hline 3.125 & 14 \\
\hline 6.25 & 45 \\
\hline 12.5 & 65 \\
\hline 25 & 19 \\
\hline 50 & 7 \\
\hline Total & 150 \\
\hline \multicolumn{2}{|c|}{ Table-III. Dose of Carvedilol } \\
\hline
\end{tabular}

Mean dose $19.37 \pm 5.76$

\begin{tabular}{|l|c|c|}
\hline & \multicolumn{2}{|c|}{ Change in Platelet Count } \\
\hline & $\begin{array}{c}\text { Pearson } \\
\text { Correlation }\end{array}$ & Significance \\
\hline $\begin{array}{l}\text { Change in systolic } \\
\text { blood pressure }\end{array}$ & 0.207 & 0.05 \\
\hline $\begin{array}{l}\text { Change in diastolic } \\
\text { blood pressure }\end{array}$ & 0.087 & 0.414 \\
\hline $\begin{array}{l}\text { Change in mean arterial } \\
\text { blood pressure }\end{array}$ & 0.149 & 0.158 \\
\hline \begin{tabular}{l} 
Change in pulse \\
\hline Dose of carvedilol
\end{tabular} & 0.244 & $\mathbf{0 . 0 2}$ \\
\hline Table-IV. Correlations of Change in Platelet Count \\
\hline
\end{tabular}

Blood pressure in $\mathrm{mmHg}$. Pulse, in beats per minute. Platelet count in 1000/microlitre

\begin{tabular}{|l|c|c|}
\hline $\begin{array}{c}\text { Changes in Platelet } \\
\text { Count (>15\% from } \\
\text { baseline) }\end{array}$ & Frequency & Percentage \\
\hline Increased & 99 & $66 \%$ \\
\hline No change & 45 & $30 \%$ \\
\hline Decreased & 6 & $4 \%$ \\
\hline Table-V. Frequency of Changes in the Platelet Counts
\end{tabular}

\section{DISCUSSION}

A total of one hundred and fifty patients were included in this study. They had liver cirrhosis due to Hepatitis C, leading to portal hypertension and splenomegaly. Such patients frequently present with upper gastrointestinal bleeding secondary to variceal bleeding and thrombocytopenia. The objective of this study is that carvedilol might improve the platelet counts in cirrhotic patients. The morbidity and mortality due to upper gastrointestinal bleeding is likely to get corrected if thrombocytopenia is treated. This will lead to cut down the need for repeated hospitalizations. The mean age of the patients was $51 \pm 8.88$ years however Sakai $K$ et $\mathrm{al}^{14}$ found the mean age of a total of 19 patients in their study to be $62 \pm 3$ years. A total of $62 \%$ patients were male and $38 \%$ were female in comparison to Sakai $\mathrm{K}$ et $\mathrm{al}^{14}$ in which they had $57 \%$ male and $43 \%$ female patients. The difference in systolic blood pressure after treatment with carvedilol was $17.03 \pm 6.58$ in comparison with the fall in diastolic blood pressure by $8.83 \pm 5.27$. A sudden 
fall in systolic blood pressure is due to the direct negative chronotropic effect of carvedilol on the beta-1 receptors in the heart. Similarly there was a significant reduction in heart rate after the administration of carvediloldue to the direct effect of this drug on the sinoatrial and atrioventricular nodes in the heart hence producing a negative chronotropic effect on the heart. The difference in mean arterial blood pressure; calculated by the formula $1 / 3$ pulse pressure + diastolic blood pressure, remains significant $p<0.05$. In contrast, Sakai K et al ${ }^{14}$ showed that there was a significant reduction $(p<0.05)$ in heart rate with carvedilol and the mean arterial blood pressure. This difference might be due to the larger sample size in our study as compared to 19 patients studied by Sakai K et al. ${ }^{14}$

Beta-2 adrenoceptors are located in the splanchnic circulatory system. According to Sakai $\mathrm{K}$ et $\mathrm{al}^{14}$ the changes in splenic circulation in the arteries with use of beta blockers were similar to the changes produced in the mesenteric arterial circulation. This was also shown by Iwao T et al. ${ }^{15}$ The mechanism behind this might be unopposed a vasoconstriction resulting from the blockade of $\beta-2$ receptors. In this study, there was a significant increase in platelet count after administration of carvedilol. The change in platelet count is significantly correlated by the changes in intrasplenic and extrasplenic arterial pulsatility indices (Sakai $\mathrm{K}$ et $\mathrm{al}^{14}$ ) These findings suggest that the platelet count is in part, regulated by the splenic arterial hemodynamics. This idea is further supported by the finding that thrombocytopenia is ameliorated after transarterial splenic arterial embolization ${ }^{16,17}$ which actually increases splenic arterial vascular resistance.

In this study, after carvedilol administration, the variation in response of platelet count can be explained by the individual variation in response of the splenic artery to carvedilol, which may be due to a difference in the number of $\beta-2$ receptors in the splenic artery. Portal hypertension causes congestive splenomegaly, which in turn causes the pooling of platelets. Thus reduction in the portal pressure induced by carvedilol may further decrease the platelet pool in the spleen. ${ }^{13}$ Indeed, it has been shown that portal decompressive procedures such as surgical portosystemic shunts ${ }^{18,19}$ and transjugular intrahepatic portosystemic shunts ${ }^{20}$ ameliorate thrombocytopenia in patients with cirrhosis. It further needs to be assessed if there is any modification of the immunological factors such as PA-IgG and thrombopoeitin production by carvedilol administration. Thus future study is needed to test this point.

\section{CONCLUSION}

1) Carvedilol improves the thrombocytopenia in cirrhosis.

2) Rise in Platelet count is inversely proportional to the pulse.

3) Pulse can be used as an indirect measure of adequate beta blockade in the splanchnic circulation.

\section{RECOMMENDATIONS}

It is recommended that Further studies with longer duration of follow up must be carried out to watch for sustained response of carvedilol on thrombocytopenia and for incidence of first variceal bleed in patients on carvedilol.

\section{Copyright $@ 25$ May, 2019.}

\section{REFERENCES}

1. Lauer G. M., Walker B. D. Hepatitis $\mathbf{C}$ virus infection. $\mathbf{N}$ Engl J Med. 2001; 345:41-52.

2. Alter M. J. Epidemiology of hepatitis $\mathbf{C}$ virus infection. World J Gastroenterol. 2007; 13:2436-41.

3. McCaughan G. W., Omata., M. Amarapurkar D., Bowden S., Chow W. C., Chutaputti A., et al. Asian Pacific Association for the Study of the Liver consensus statements on the diagnosis, management and treatment of hepatitis $\mathbf{C}$ virus infection. J Gastroenterol Hepatol. 2007; 22:615-33.

4. Poynard T., Yuen M. F., Ratziu V., Lai C.L. Viral hepatitis C. Lancet. 2003;362: 2095-100

5. WHO. World Health Report 2002. Annex table-II: Deaths by cause, sex and mortality stratum in WHO regions, estimates for 2001. wwwhoint/entity/whr/2002/en/ whr2002_annex2pdf [Accessed on August 21, 2008]. 
6. Nadeem M.A., Waseem T., Sheikh A.M., Grumman N, Irfan K, Hasnain S.S. Hepatitis C virus: an alarmingly increasing cause of liver cirrhosis in Pakistan. Pak J Gastroenterol 2004; 23: 45-6

7. Khan R. A., Ahmed W., Alam E., Arif A. Screening of HBsAg and Anti HCV from Tertiary Care, Private and Public Sector Hospital PMRC Research Centre1, PMRC Specialized Research Centre on Gastroenterology and Hepatology2, 3, 4, Jinnah Postgraduate Medical Centre, Karachi. Pak J Med Res. Vol. 50, No. 1, 2011.

8. Al-Busafi S. A., Baltar J. M., Farag A., and Hilzenrat N. Clinical Manifestations of Portal Hypertension. International Journal of Hepatology Volume 2012, Article ID 203794, doi:10.1155/2012/203794.

9. Gluud L. L., Klingenberg S., Nikolova D., Gludd C. Banding ligation versus beta-blockers as primary prophylaxis in esophageal varices: Systematic review of randomized trials. Am J Gastroenterol. 2007; 102:2842-8.

10. Reiberger T., Ulbrich G., Ferlitsch A., Payer B.A., Schwabl P., Pinter M., et al. Gut. 2013; 62: 1634-41.

11. Kim M. Y., Iwakiri Y. Can hypersplenism secondary to portal hypertension be treated by non-selective beta blockers? Hepatol Int 2015 Jan 25; 9:337-338.

12. Abid S., Ali S., Baig M. A., Waheed A. A. Is it time to replace propranolol with carvedilol for portal hypertension? World J Gastrointest Endosc 2015 May 16; 7(5): 532-539. ISSN 1948-5190 (online)

13. Kutti J, Weinfeild A, Westin J. The relatioship between splenic platelet pooling and the pathogenesis of hypersplenism. Am J Med Sci 1967; 253: 383-97
14. Sakai K, Iwao T, Oho K, Toyonaga A, Sata M. Propranolol ameliorates thrombocytopenia in patients with cirrhosis. J Gastroenterol. 2002; 37: 112-8.

15. Blognesi M, Sacerdoti D, Merkel C, Gerunda G, Maffei-Faccioli A, Angeli P, et al. Splenic Doppler indices: influence of different portal hemodynamic conditions. Hepatology 1996; 23: 1035-40

16. Sangro B, Bilbao I, Herrero I, Corrella C, Longo J, Beloqui $O$, et al. Partial splenic embolization for treatment of hypersplenism in cirrhosis. Hepatology 1995; 216: 1203.

17. Alvarez OA, Lopera GA, Patel V, Encarnacion CE, Palmaj JC, Lee M. Improvement of thrombocytopenia due to hypersplenism after transjugular intrahepatic portosytemic shunt placement in cirrhotic patients. Am J Gastroenterol 1996; 91: 2249

18. Ferrara J, Ellison EC, Martin EW Jr, Cooperman M. Correction of hypersplenism following distal splenorenal shunt. Surgery 1979; 86:570-3.

19. Yanaga k, Tzakis AG, Shimada M, Campbell WE, Marsh JW, Steiber AC, et al. Reversal of hypersplenism following orthotopic liver transplantation. Ann Surg 1989; 210 : 180-3

20. Noronha R, Taylor BA, Wild G, Triger DR, Greaves M. Interrelationships between platelet count platelet IgG, serum IgG, Immune complexes and severity of liver disease. Clin lab Haematolo 191; 13: 127-35

\begin{tabular}{|c|c|c|c|}
\hline \multicolumn{4}{|c|}{ AUTHORSHIP AND CONTRIBUTION DECLARATION } \\
\hline Sr. \# & Author(s) Full Name & Contribution to the paper & Author(s) Signature \\
\hline 1 & $\begin{array}{l}\text { M. Jahangir Mujahid } \\
\text { Sobia Khalid }\end{array}$ & $\begin{array}{l}\text { Conception, Design \& } \\
\text { Acquisition of data. } \\
\text { Drafting of article. }\end{array}$ & \\
\hline 3 & Shehla Mujahid & Interpretation of data. & ajalid. \\
\hline 4 & Muhammad Riaz & Critical revision of data. & Walk \\
\hline 5 & Khurram Malik & Acquisition of data. & \\
\hline 6 & Arif Amir Nawaz & Proof reading. & \\
\hline
\end{tabular}

